\title{
Geoethics in Hollywood: How Can We Put More Reality into Fault Hazard Zoning?
}

\author{
ELDON M. GATH \\ TANIA GONZÁLEZ \\ Earth Consultants International, Santa Ana, CA, USA \\ gath@earthconsultants.com; tgonzalez@earthconsultants.com
}

\begin{abstract}
The 15-km-long Hollywood fault extends through some of the most densely developed and expensive areas in southern California. Given that billions of dollars of real estate could be impacted by an earthquake occurring on the fault, and that tens of thousands of people live near it, the seismic hazard posed by the Hollywood fault is concerning. But how much so? The City of West Hollywood has required geological fault investigations and building avoidance of at least 15 meters from the fault's active trace since the mid-1990s, resulting in numerous site investigations. Geologic studies in support of the Los Angeles Metro subway and subsequent research found as-yet-unconfirmed equivocal evidence of an early Holocene-age ( $>\mathrm{ka})$ displacement event, and estimated strain rates of 0.3-0.9 mm/yr. In 2014, and following a "not-in-my-backyard" press campaign against the Hollywood Millennium project, the California Geological Survey zoned the eastern Hollywood fault as Holocene-active under their fault zoning program, requiring geological investigations and building setbacks from Holocene-age faults. In the years since the fault was zoned by the City of West Hollywood and the California Geological Survey, millions of dollars have been invested in geological studies of the fault for building projects. All of these dollars have been reluctantly spent by the private sector, and all of this work has been eagerly done by consulting firms. The results? With only four exceptions, two in West Hollywood, and two in the City of Los Angeles, and all having opportunities for alternative interpretations, no Holocene-age fault displacements have been found. Instead, other studies have found definitive evidence that the fault has not ruptured in 10s to 100s of thousands of years. So what is the ethical alternative? Should we ignore the hazard posed by the fault? A re we geo-professionals too enamored of the financial gains such regulatory zoning provides that we are unwilling to suggest changes? Could we move past the "one size fits all" zoning that requires that single-family homes are held to the same standard as 40-story buildings? In the following sections we present several case studies along the Hollywood fault and provide our suggestions for a more progressive program of fault hazard management.
\end{abstract}

\section{INTRODUCTION}

$\mathrm{T}$ he Hollywood fault is mapped as an east- to northeast-trending structure along the southern margin of the Santa Monica Mountains (locally referred to as the Hollywood Hills), placing late Jurassic metamorphic and Cretaceous to Miocene granitic and sedimentary rocks on the north against the Quaternary-aged valley fill of the Hollywood Basin. Most recent maps generally show the Hollyw ood fault extending from the west bank of the Los Angeles River westward, through the cities of Los Angeles, West Hollywood and Beverly Hills, a distance of about 15 km (Fig. 1 and 2). The fault is considered part of the approximately $230-\mathrm{km}$-long fault system at the southern edge of the Transverse Ranges physiographic province of southern California. Nearby faults that are also part of this system include the Raymond and Sierra Madre faults to the east, and the Santa Monica, and Malibu Coast faults to the west.

\section{MAPPING OF THE HOLLYWOOD FAULT THROUGH TIME}

As early as 1931, Hoots and Kew prepared the first comprehensive geologic map of the area, and inferred the Santa Monica-Hollywood 


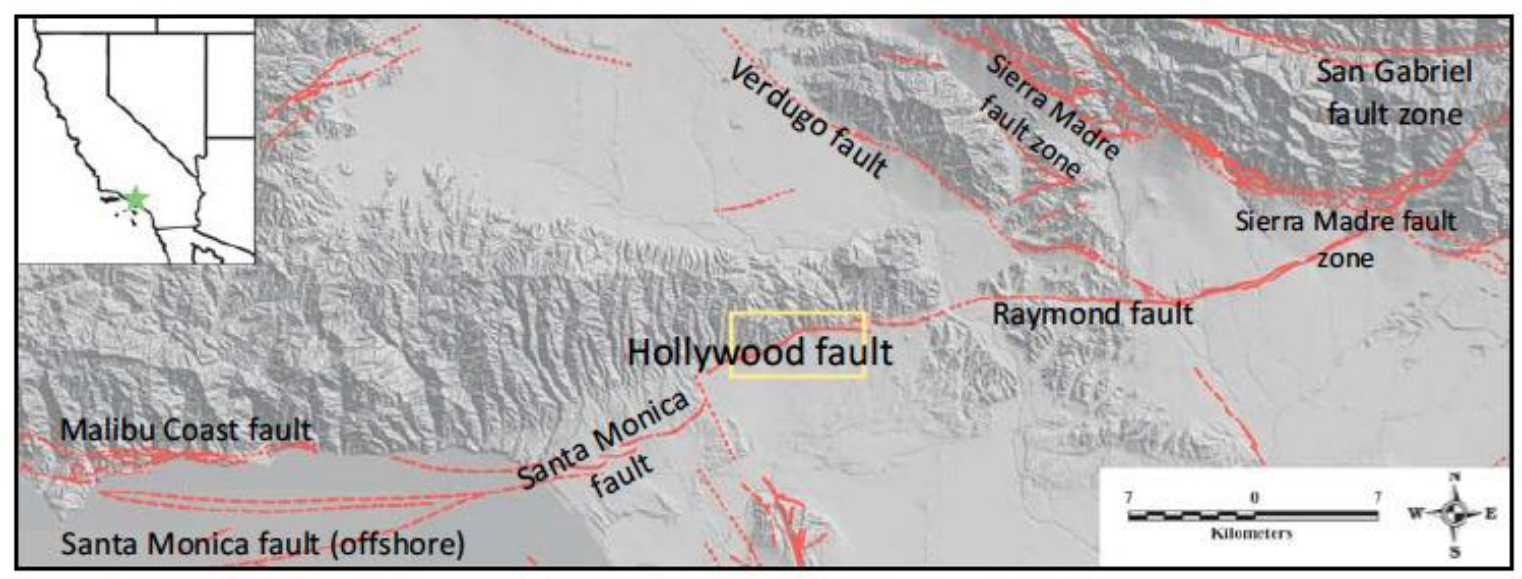

Figure 1: Location of the Hollywood fault at the base of the Hollywood Hills, forming the northern boundary to the Hollywood basin. The fault is considered a short segment of the approximately E-W to NE-WSW system of faults that include the Santa Monica, Malibu Coast, Raymond and Sierra Madre faults shown on this figure. Additional faults that are thought to be part of this system occur farther west and east, respectively, of the mapped image. Yellow square shows the area covered in Figures 2 and 3.

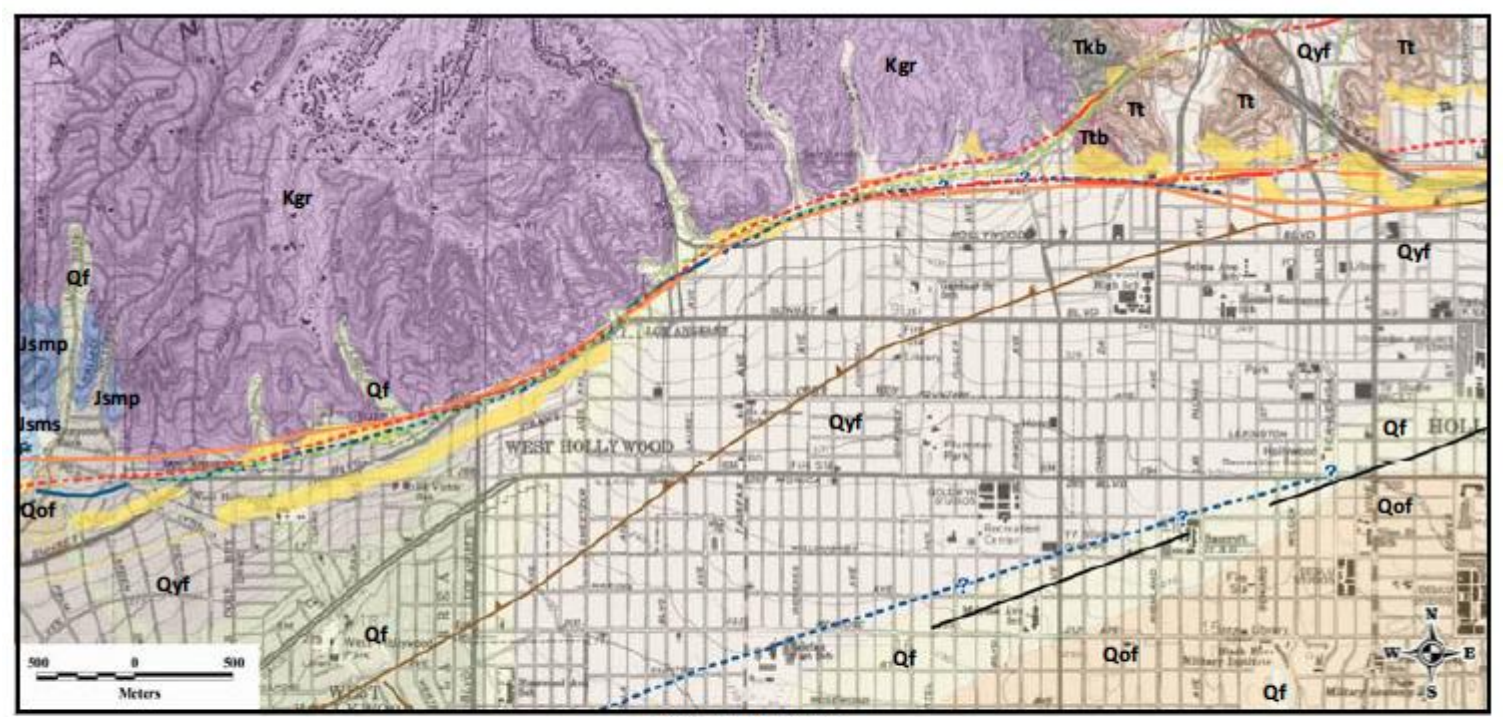

\section{EXPLANATION}

\section{MAPPED FAULTS}

-- Hoots and Kew (1931)

-.- Hill et al. $(1978,1979)$

--- Dibblee (1991a, 1991b)
Crook and Proctor (1992)

$\sim$ Lang and Dreesen (1975)

- Schneider et al. (1996)
MAPPED SCARPS and FOLDS

Dolan and Sieh $(1992,1997)$

Figure 2: Various interpretations of the location of the Hollywood fault using Dibblee's (1991a, b) geologic maps as a base. Note that in the east-central portion of the map, most researchers place the fault in almost the same area, whereas to the west and east, the interpreted fault locations vary, sometimes significantly.

faults as buried structures at or near the sharp break in slope along the southern margin of the Santa Monica Mountains. The fault, or sections of the fault zone, were also mapped by Lamar (1970), Hill et al. (1978, 1979), Weber et al.
(1980), Crook and Proctor (1992), with map compilations by Dibblee (1991a, b) and Yerkes and Campbell (2005).

The most detailed mapping of the HollywoodSanta Monica fault was done by Dolan et al. 
(1992, 1997), who utilized U.S. Geological Survey 1920 s vintage 5 -foot $(\sim 1.5 \mathrm{~m})$ contour topographic maps of the area to map scarps, fans and other potentially fault-related topographic features now hidden by urban development.

Dolan et al. $(1992,1997)$ identified several linear scarps and faceted south-facing ridges (see yellow zones in Fig. 2) that they interpreted as
Notably, in the West Hollywood and Beverly Hills areas, Dolan et al. $(1997,2000)$ interpreted the Hollyw ood fault south of the main break in slope that Hoots and Kew (1931) and most other researchers had used to infer the location of the fault. Several fault-location studies in the West Hollywood area have been conducted since the mid-1990s. About a third of these

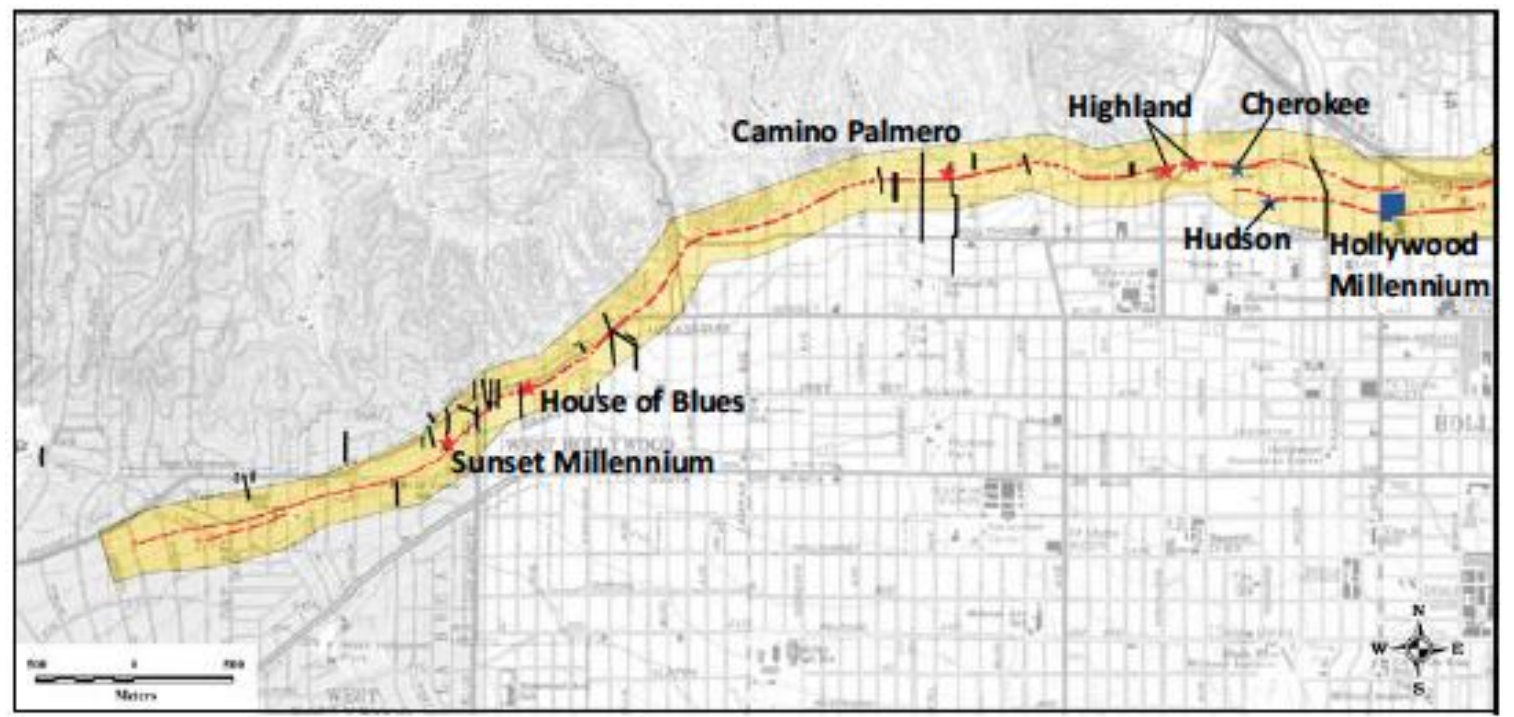

Figure 3: Part of the zone of required investigation (yellow area) established by the California Geological Survey (CGS, 2014) for the Hollywood fault. Any property within the yellow zone is required to be investigated for possible active faulting prior to it being developed or re-developed. Blue stars denote sites discussed in the text where faults found to be not active were exposed in trenches or were interpreted from transects of CPTs and borings; red stars show the only sites where radiocarbon-dated sediments have suggested the occurrence of Holocene-active faults. The black lines show the location and extent of transects across the fault zone that were conducted between the 1980s and approximately 2014. Since the fault was zoned, several additional studies have been conducted; only a few of these (such as Cherokee, Hudson, and Hollywood Millennium) are included here.

the near-surface expression of the fault. Where the scarps are broad features 15 to $60+\mathrm{m}$ wide, the researchers combined the geomorphic data with subsurface information obtained from geotechnical and groundwater studies in an attempt to better constrain the location of the major traces of the Hollywood fault. Hoots (1931) and other early researchers had inferred the fault to be primarily a north-dipping reverse structure responsible for the growth of the adjacent Hollyw ood Hills. How ever, based on the fault's linear trace and steep 80- to 90-degree dips observed in down-hole logged borings, Dolan et al. (1997, 2000) interpreted the fault as primarily left-lateral strike-slip with a small amount of north-side up, reverse component. studies have encountered or interpreted faults, and the locations of these have roughly agreed with Dolan et al.'s $(1997,2000)$ fault scarps, although the zone of faulting has been shown to be wider and more complex, interpreted to consist of both north-dipping reverseseparation structures, and south-dipping normal faults within the hanging wall. Significantly, however, only one of these faults has been interpreted as Holocene active, based on the findings at the Sunset Millennium and House of Blues sites (on the far left in Fig. 3), where radiocarbon-dated samples were collected from above and below the fault zone in down-hole logged borings. Several of these studies also found that the steep step in the bedrock that 


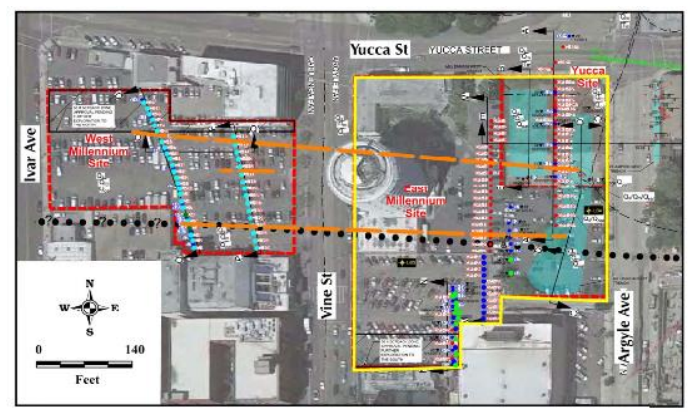

Figure 4a: Map showing the extensive data set used to evaluate the Hollywood Millennium sites, including trenches (in light turquoise), CPTs (in red), and continuously sampled borings (in blue). The inferred location of the Yucca Street section of the Hollywood fault shown by the black dots. Two faults (orange lines) were interpreted from the subsurface data; these faults are minor and have not moved in at least 100,000 years.

was previously interpreted as a fault scarp (Hoots and Kew, 1931; Dibblee, 1991a, b) is an ancient beach seacliff. Trenches and borings have exposed an old marine abrasion (wavecut) platform and associated marine deposits estimated to be at a minimum 400,000 to 900,000 years old (summarized in Hernandez and Treiman, 2014; Hernandez, 2014). Similar marine sediments have been observed at depth both to the west and east, in Beverly Hills and Hollyw ood, respectively.

The Hollywood fault was interpreted or observed in some of the transects conducted for infrastructure projects such as the Los Angeles (LA) Metro Red Line along Camino PalmeroMartel Avenue, and La Brea Avenue, the LA MetroRail project along Cahuenga Boulevard, and storm drain trenches along Vista Street and Fuller Avenue (Dolan et al., 1997). Dolan et al. (2000) revisited the Camino Palmero-Martel Avenue location and used a series of closely spaced down-hole logged borings to better locate and study the fault. The findings from that study suggested that the most recent surfacerupturing earthquake (MRE) on the Hollyw ood fault occurred about 7,000 to 9,500 years ago, with a possible penultimate event about 22,000 years ago, indicating a long interval between earthquakes, and an unconfirmed estimated strain rate of $0.3-0.9 \mathrm{~mm} / \mathrm{yr}$. Given its length,

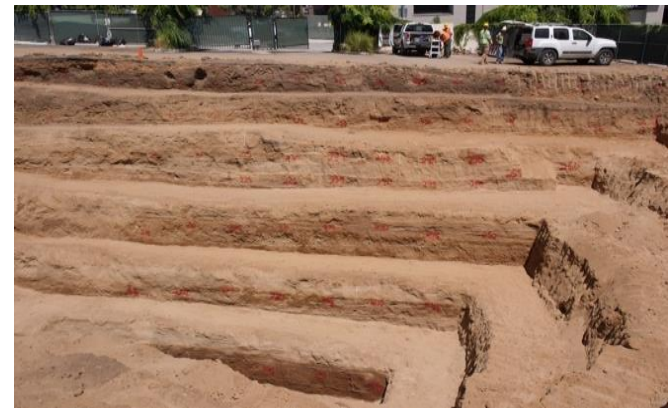

Figure 4b: Photograph showing a portion of the $9+m$ deep trench excavated in the parking lot of the Tower Records building, which is also the East Millennium site. The footprint of the trenches is shown in light turquoise on the figure to the left. A demonstrably not active fault with about $50 \mathrm{~cm}$ of total displacement was exposed near the bottom of the trench. Photo courtesy of Group Delta Consultants.

the Hollywood fault is only capable of generating about a $\mathrm{Mw} \sim 6.6$ earthquake. To produce a larger-magnitude earthquake requires that the fault rupture together with other faults to the west and east, such as the Santa Monica, Malibu Coast and Raymond faults. The existing paleoseismic data, however, show that each of these faults has a significantly different earthquake history, with thousands of years between events on different faults. Thus, the available data suggest that the Hollywood fault ruptures independently, has a slow rate of slip, and takes thousands of years to reach its breaking point. Assuming the MRE age and strain rate are correct, the fault has accumulated between 2.1 and $8.5 \mathrm{~m}$ of strain, unlikely high values for such a short fault.

Following the City of West Hollywood example from the mid-1990s, the City of Los Angeles began requiring fault studies in the Hollywood area in the early 2000s. Then in 2014, that portion of the Hollywood fault in the Hollywood quadrangle was zoned by the California Geological Survey under the provisions of the 1972 Alquist-Priolo Earthquake Fault Zoning Act (Figure 3; Hernandez and Treiman, 2014; Hernandez, 2014; CGS, 2014). As a result of these requirements, several studies have been conducted in the Hollywood area (summarized in Hernandez and Treiman, 2014; Hernandez, 


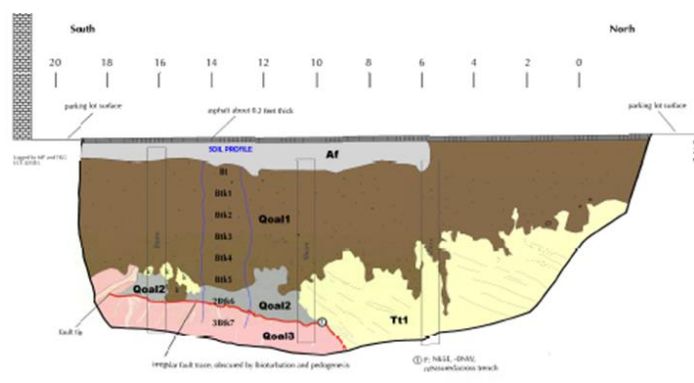

Figure 5: Log of southern end of Trench ECI-1 at the Cherokee Avenue site showing the fault in red, and the geologic units described in the text.

2014). Both the northern and southern traces show $n$ on the eastern one-third of the zoning map have been the subject of these studies. However, only two of these consulting studies, both on Highland Avenue, have interpreted active (Holocene) traces of the Hollyw ood fault within the zone.

\section{SITE-SPECIFIC FAULT STUDIES}

\subsection{Hollywood Millennium Sites and Hudson Avenue}

The proposed East and West Hollywood Millennium sites (far right on Figure 3) extend across the Yucca Street section of the Hollywood fault as mapped by CGS on their Alquist-Priolo (A-P) map. The geotechnical consultants for this project (Group Delta Consultants) pushed more than 100 cone penetrometer test (CPT) probes, drilled and logged more than 30 continuously cored borings, and excavated and logged two trenches with a combined total length of more than $120 \mathrm{~m}$ (Fig. 4). These studies have shown that the area is underlain by $\sim 10 \mathrm{~m}$ of Holocene-aged allu vium deposited within a canyon that was carved into Pleistocene-aged mudflow deposits and, in the northern portion of the study area, Topanga Formation $(\sim 15 \mathrm{Ma})$ bedrock and older alluvial fan deposits that significantly pre-date the mudflow deposits. These subsurface studies suggest the presence of at least two minor faults under the area, with last movement on these faults occurring between about 100,000 and 150,000 years ago. Thus, the area is not underlain by active faults, contrary to the CGS' map that indicates the active Hollywood fault extends through this site. Similarly, CPTs and borings drilled along a section of Hudson Avenue encountered a discontinuity in the deeper layers that is either an erosional surface or a fault. The feature is overlain by several unbroken layers of older alluvium modified by soilforming processes. The degree of soil development exhibited by these alluvial sediments indicate that if the discontinuity is faultcontrolled, the fault has not moved in at least 50,000 years. This estimate is considered a minimum value given that most of the overlying unbroken soils were truncated, indicating significant erosional periods.

\subsection{Cherokee Avenue Sites}

To date, three separate studies have been conducted off Cherokee Avenue, in Hollywood. The first study found faulted bedrock with no overlying alluvial sediments from which to determine fault activity; the CGS chose to consider the fault active (see Hernandez et al., 2014). In 2016 we conducted a study immediately to the south. Our easternmost trenches exposed the Hollywood fault placing bedrock of the Topanga Formation (Tt) over Pleistocene age alluvium (Fig. 5). The fault dipped to the north at about 40 degrees at the bottom of the trenches, but rolled over to nearly horizontal, forming the contact between two older alluvial deposits. The fault tip thrust Qoal2 under Qoal3 during its last surface-rupturing earthquake. The fault could not be traced upward into the upper section of the Qoal2 unit, as this contact was intensely bioturbated. In a parallel trench, however, the top of the Qoal1 unit was clearly not broken, so we are certain that the fault has not moved since the soil in the Qoall unit formed. Our age estimates for that unit, based on degree of soil development, range from about 160,000 to 230,000 years, so this fault has not moved in at least 160,000 years, a finding that was later confirmed by others on an adjacent property.

\section{DISCUSSION}

Despite extensive and costly investigations, evidence that the Hollywood fault is active re- 
mains elusive. The published findings of an early Holocene displacement, and media coverage of opposition to the Hollywood Millennium project led the CGS to consider the fault suitable for A-P zoning. The two zoning criteria used by the CGS are "sufficiently active" (i.e. Holocene/ 11,700 ybp) and "well defined." If the few studies suggesting Holocene activity (Hernandez and Treiman, 2014), are correct, the Hollywood fault might meet the extreme minimum condition of Holocene-active, but its active trace is certainly not well defined, as demonstrated by the numerous other studies attempting, and failing, to find it. Considering the millions of dollars invested by private developers in these studies, can we not develop a more progressive method of achieving earthquake safety along this, and other similarly poorly defined, low-slip faults?

California law for active fault zoning specifies avoidance of the fault trace as the only permitted mitigation alternative if the fault has experienced even a single, minor Holocene displacement. This binary, one-size-fits-all choice has led many owners to not update their existing older buildings because a fault study would be required before they can redevelop. If a Holocene fault is found under their site, the owner would likely be prohibited from undertaking structural modernization for seismic safety. Thus, one of the law's unintended consequences is the preservation and continued use of structures that are seismically unsafe from high-probability regional earthquake events becau se of the low -probability of surface fault rupture through their site. We propose a more progressive approach to mitigate the hazard of surface fault rupture that takes into account the forty years of earthquake geology knowledge gained since the law was enacted.

We suggest that surface fault rupture mitigation be incorporated into the building code, rather than being codified into law. In doing so, geologists will be tasked with determining the fault's location and rupture kinematics, timing of prior events, and estimated time to the next event. Then, based on the type of structure proposed, a risk management approach would be employed scaled to the hazard and the risk, similarly to all other geologic risk factors (seismic shaking, ground failure, slope failure, liquefaction, flooding, etc.) that are already considered in the building code. Thus, for single-family residential homes, a fault would be subject to mitigation requirements if the fault lies within 500 years of its average recurrence interval. For larger residential and commercial structures, the fault would be subject to mitigation if it lies within 1000 years of its average recurrence interval, and for critical infrastructure and facilities, that interval could be 1500 or 2500 years. These hazard windows are similar to those for seismic structural design, liquefaction and landslide geotechnical stabilization, and exceed those for flood hazards. Mitigation alternatives might include structural isolation or reinforcement, soil strengthening, or avoidance, depending upon the anticipated fault's displacement, site conditions, and economic or social value.

Continuing down the forty-year-old path of strict avoidance for any Holocene-age fault, despite its displacement history or magnitude, can no longer be defended as a cost-effective solution to improve public safety. Intelligent and progressive mitigation of known and properly quantified hazards is the basis of all performance-based designs, and it is time for California's geologists, and the California Geological Survey, to move on from the A-P Act by either modernizing or sunsetting it, and letting the building code process handle fault rupture hazard as just another geologic factor in land planning and development. It is the ethical thing to do.

\section{ACKNOWLEDGEMENTS}

Thank you to Maria Herzberg of Earth Consultants International for preparing Figures 1 through 3. The report was improved following comments and edits to the original manuscript provided by Umberto Fracassi, an anonymous reviewer, and Giuseppe Di Capua. Thank you for your valuable and honest feedback.

\section{REFERENCES}

California Geological Survey (CGS) (2014). Earthquake Fault Zones of Required Investigation, Hollywood 7.5 Minute Quadrangle, official map released in November 6, 2014.

California Geological Survey (CGS) (2018). Earthquake Fault Zones of Required Inves- 
tigation, Beverly Hills 7.5 Minute Quadrangle, revised official map released January 11, 2018.

Converse Consultants, Earth Science Associates, and Geo/ Resource Consultants (1983), Seismological Investigation and Design Criteria, for Southern California Rapid Transit District, Metro Rail Project, dated May 15, 1983, Parts 1 and 2 (as referenced in Hernandez and Treiman, 2014).

Crook R. Jr. and Proctor R.J. (1992). The Santa Monica and Hollywood faults and the southern boundary of the Transverse Ranges Province. In: Pipkin B.W. and Proctor R.J. (editors), Engineering Geology Practice in Southern California. Association of Engineering Geologists, Southern California Section, Special Publication No. 4, pp. 231-246 (published by Star Publishing Company).

Dibblee T.W. Jr. (1991a). Geologic Map of the Hollywood and Burbank (South 1/2) Quadrangles, Los Angeles County, California. Dibblee Geological Foundation Map \#DF30, Scale: 1:24,000.

Dibble T.W. Jr. (1991b). Geologic Map of the Beverly Hills and Van Nuys (South 1/2) Quadrangles, Los Angeles County, California. Dibblee Geological Foundation Map \#DF-31, Scale: 1:24,000.

Dolan J.F., Sieh K., Rockwell T.K., Guptill P., and Miller G. (1997). Active tectonics, paleoseismology, and seismic hazards of the Hollywood fault, northern Los Angeles basin, California. Geological Society of America Bulletin, Vol. 109, No. 12, pp. 1595-1616.

Dolan J.F., Donovan S., and Rockwell T. (2000). Paleoseismic Evidence for an Early to MidHolocene Age of the Most Recent Surface Rupture on the Hollyw ood Fault, Los Angeles, California. Bulletin of the Seismological Society of America, Vol. 90, No. 2, pp. 334344.

Dolan J.F. and Sieh K.E. (1992). Structural style and tectonic geomorphology of the northern Los Angeles Basin: Seismic hazards and kinematics of recent fault movement. Association of Engineering Geologists, Proceedings of the 35th Annual Meeting, pp. 621622.

Hernandez J.L. (2014). The Hollywood Fault in the Hollywood 7.5' Quadrangle, Los Ange- les County, California. California Geological Survey, Fault Evaluation Report FER 253, Supplement No. 1, dated November 5, 2014.

Hernandez J.L. and Treiman J.T. (2014). The Hollywood fault in the Hollywood 7.5' Quadrangle, Los Angeles County, California. California Geological Survey, Fault Evaluation Report FER 253, dated February 14, 2014.

Hill R.L., Sprotte E.C., Bennett J.H., Real C.R., and Slade R.C. (1979). Location and activity of the Santa Monica fault, Beverly Hills Hollywood area, California. In: Hill R.L., Sprotte E.C., Chapman R.H., Chase G.W., Bennett J.H., Real C.R., Slade R.C., Borchardt G., and Weber F.H. Jr. (1979), Earthquake hazards associated with faults in the greater Los Angeles area, Los Angeles County, California, including faults in the Santa Monica-Raymond-Verdugo-Eagle Rock and Benedict Canyon fault zones. California Division of Mines and Geology, Open File Report 79-16-LA (Final Technical Report, U.S.G.S. Grant No. 14-08-0001-G510), pp. B-1 to B-42.

Hoots H.W. (1931). Geology of the Eastern Part of the Santa Monica Mountains, Los Angeles County, California. U.S. Geological Survey Professional Paper 165-C, pp. 83-134, map scale: 1:24,000.

Hoots H.W. and Kew W.S.W. (1931). Geologic map of the eastern part of the Santa Monica Mountains and adjacent areas, Los Angeles County, California. In: Hoots H.W., Geology of the Eastern Part of the Santa Monica Mountains, Los Angeles County, California: U.S. Geological Survey Professional Paper 165-C, Plate 16, map scale: 1:24,000.

Lamar D.L. (1970). Geology of the Elysian ParkRepetto Hills area, Los Angeles County, California. California Division of Mines and Geology Special Report No. 101, 45p.

Lindvall S., Rockwell T., Kasman G., and Helms J.G. (2001). Style, activity, and uplift rate of the Hollywood fault in Hollywood and West Hollywood, California. [Abstract] Geological Society of America - Cordilleran Section 97th Annual Meeting and American Association of Petroleum Geologists - Pacific Section Meeting, April 9-11, 2001, Session No. 12, Los Angeles, California. 
Weber F.H. Jr., Bennett J.H., Chapman R.H., Chase G.W., and Saul R.B. (1980). Earthquake Hazards Associated with the Verdugo-Eagle Rock and Benedict Canyon Fault Zones, Los Angeles County, California. California Division of Mines and Geology, Open File Report 80-10 LA.

Yerkes R.F. and Campbell R.H. (2005). Preliminary Geologic Map of the Los Angeles 30'x60' Quadrangle, Southern California, Version 1.0. U.S. Geological Survey OpenFile Report 2005-1019, available from http:// pubs.usgs.gov/ of/ 2005/ 1019 (accessed 15 May 2018). 